\title{
Strategic Alliance, Information and Communication Technology, and Customer-Related Performance: The Role of Industry Characteristics
}

\author{
Lanita Winata \\ Griffith University \\ E-Mail: 1.winata@griffith.edu.au \\ Lokman Mia \\ Griffith University \\ E-Mail: 1.mia@griffith.edu.au \\ Christian Langmann \\ Helmut Schmidt University \\ E-Mail: koller@hsu-hh.de
}

\begin{abstract}
Purposes: This study investigates whether the relationship between a firm's engagement in strategic alliance and its customer-related performance (CRP) is direct or indirect through the managerial use of information and communication technology (ICT).

Methodology: The results are based on the responses of 78 general managers from large manufacturing firms, and the data were analysed using structural equation modelling with partial least squares (PLS).

Findings: The results reveal that a firm's engagement in a strategic alliance is positively related with the firm's CRP—not directly, but through the managerial use of the ICT. The results also reveal that the relationship is industry specific.

Limitations: The results may be manufacturing industry specific, so caution is necessary in generalising the results to other industries. Furthermore, this study does not consider the different types of strategic alliances in which a firm can engage. The extant literature suggests that a strategic alliance may be vertical or horizontal, internal or external.
\end{abstract}


Practical implications: The results indicate that an organisation which engages in a strategic alliance to improve its desired performance needs to have an appropriate ICT facility.

Originality: This study investigates the role of ICT on the strategic alliance and firm performance relationship in Indonesia.

Keywords: Strategic Alliance, ICT, Performance

\section{INTRODUCTION}

In today's globally competitive e-commerce market, customers have more choices. In such a challenging environment, companies are subject to threats from both local and overseas competitors. The extant literature suggests that, to overcome such threats, a firm must keep its customers satisfied. On the one hand, a competitive e-commerce offers customers various opportunities to compare and buy products online; on the other hand, it provides organisations with new ways to conduct business and exchange/communicate information. Consequently, the market becomes increasingly competitive as customers can get easy access to more product information and are able to buy products and services online from anywhere. Companies usually spend big money to market their products, both to get new customers and retain existing customers. However, in the current global e-commerce market, companies using only traditional product-promotion activities may not survive (O'Connell, 2002). The relevant literature suggests that, to survive in the market, companies have to improve their customer-related performance to get new customers and retain the existing ones.

Customer-related performance, which is usually driven by customer satisfaction, has been regarded as a critical determinant of long-term customer behaviour. The more satisfied customers are, the more loyal they are to the products (Ranaweera \& Prabhu, 2003), which in turn leads to increased sales and market shares. Kim (2010), for instance, reported that satisfied customers show loyalty to a company through repeat as well as increased purchases of its products and services as well as recommendation of the products/services to others; they are also less sensitive to price. Compared to getting new customers, satisfied customers are also less expensive to retain, thereby generating financial benefits at relatively lower marketing costs (see Ranaweera \& Prabhu, 2003). Following the literature, we consider that a company's customer-related performance contributes to its success.

The relevant literature suggests that, as the market becomes more and more competitive, companies find it harder to maintain or improve their customer 
satisfaction by increasing their product range, improving the quality of products and services, offering better value for money, and penetrating into new and/or overseas markets (Kaplan \& Norton, 1996; Whipple, 2000). One way to achieve such an objective is to engage in strategic alliance(s) with other firms. Gulati (1998, p. 293) defined a strategic alliance as "voluntary arrangements between firms involving exchange of technologies, sharing of services, and/or co-development of products." They can occur as a result of a wide range of motives and goals, take a variety of forms, and occur across vertical and horizontal boundaries. Engaging in a strategic alliance allows the alliance member firms to jointly undertake research and development; share knowledge, costs, and risks in developing new products; and share processes and services (Connell \& Voola, 2007; Hill, 2010). It is also a way of bringing together complementary skills and resources that a firm could not easily develop alone.

We view that the managerial use of information and communication technology (ICT) can facilitate the positive effect of a firm's strategic alliance on its performance. ICT comprises the Intranet and Internet, including net-meeting, netphone, and videoconference. Andersen and Segars (2001) suggested that the managerial use of ICT can help a firm maximise the benefits of its engagement in a strategic alliance, particularly when a manufacturing firm operates in a highly competitive market, offering a broad range of products, maintaining a number of divisions in different regions or countries, and employing a large number of personnel.

\section{THEORY AND HYPOTHESIS DEVELOPMENT}

In this section we explain the relationship between engagement in a strategic alliance (SA) and the managerial use of ICT, followed by discussion of the relationship between ICT and customer-related performance (CRP). Finally, the relationship between SA and ICT is discussed.

\section{Engagement in SA and Managerial Use of ICT}

Due to globalisation, technological advancements, and deregulations of economy, competition has intensified globally, resulting in increasing customer expectations. Today's customers demand the rapid processing and on-time delivery of orders. To successfully such customer demands and preferences, companies need to implement innovative strategies that capitalise on both the power of ICT and the changes in market demands and preferences. We contend that SA is one such strategy. We also consider that a successful SA requires a communication system built on stateof-the-art ICT. The Internet and intranet are examples of such ICT that can support the 
success of a strategic alliance. The managerial use of the Internet links alliance member firms together, making it easy for the members to have on-time access to each other's information and resources to jointly develop products and/or services, conclude contracts, share promotional plans, negotiate prices, and identify potential markets. In other words, the Internet as a business-to-business communication tool facilitates the on-time flow of information between alliance member firms, integrating the business processes across the extended enterprise, including customers, suppliers, marketing, and services (Papazoglou et al., 2000). An intranet is critical for the timely communication and flow of information among managers within an alliance member firm which, in turn, facilitates communications between alliance member firms.

Many studies have examined the effectiveness of engagement on a firm's performance. However, the results of these studies have been mixed. For example, Harrigan (1985) reported that the success rate of such alliances is low. About $70 \%$ of $\mathrm{SA}$ fail to maintain relationships between member organisations and, therefore, lose the benefits of the alliance. One reason for such failure is the lack of effective communication among the member organisations of an alliance. For instance, Shrader (2001) and Steensma and Corley (2000) suggested that the biggest obstacles to the success of a SA are lack of close communication and collaboration between the member firms (see also Haywood, 1999). Pearce and Robinson (2011) also reported that many SAs fail to achieve the objectives because of a lack of commitment and trust among alliance members. Elmuti, Abou-Zaid, and Jia (2012) investigated the effect of SA in five different countries; their result showed that the engagement improved organisational performance through interactive learning processes, communication, and information sharing among SA partners. These results indicate that communication and collaboration form the basis of inter-firm relationships. Furthermore, given that a SA may take the form of a horizontal and/or vertical interfirm relationship, it may result in an integrated value chain (Papazoglou et al., 2000). From this point of view, SA requires a workflow distribution providing a sequence of business activities, arrangements for the deliveries of work to the appropriate organisational sites or facilities, tracking of the status of business activities, and coordination of the flow of information on activities.

As previously suggested, the success of the engagement in SA is the existence of strong collaboration through communication. Nowadays, ICT is the most common technology used to communicate compared with other conventional communication technology. ICT is the most convenient and cheapest communication technology. This advanced communication technology allows people to communicate rapidly and breaks through the geography barrier (Forousan, 2001). The results of prior studies 
show that, by using ICT, member firms of an alliance can take advantage of each other's core competencies, resulting in the success of the SA (Brynjolfsson \& Hitt, 1996). Similarly, Andersen (2001) suggested that the use of ICT enables the member firms' business processes to track transactions across departments, companies, and enterprise boundaries. Furthermore, Dewett and Jones (2001) suggested that ICT brings efficiency to the relationship among alliance member firms as well as between a firm's different areas, especially transaction costs as all information can be transmitted through computer networks and used at a low cost. Other studies have shown that the successful operation of a SA is facilitated as every member firm of the alliance is able to share information with trading partners and customers on a real-time basis. The real-time flow of communication allows the alliance members to exchange information freely and promptly and helps build up their relationship, collaboration, and commitment, thereby promoting trust and commitment among them (see Shrader, 2001; Adobor, 2002). Villas and Macedos-Soares (2007) reported that this leads to managerial use of ICT to strengthen collaborations among SA members. Luo (2008) and Lee and Ding (2010) suggested that the integration among alliance member firms has a positive effect on alliance integration, which in turn facilitates alliance success. Lee and Ding (2010) also suggested that the use of communication technology, such as the Internet, is key to the success of a firm's engagement in strategic alliance. Indonesia is a developing country with a collectivist culture (Hofstede, 1994). Triandis (1995) explained that, under collectivism, trust and social norms drive the initial cooperation. However, this suggestion has been contested by other researchers. For example, although Wong and Tjosvold (2006) contended that only collectivist cultures value integrated interaction among partners, Chen, Chen, and Meindl (1998) found that only individualists develop trust to enhance cooperation. Given that Indonesia is a country with a collectivist culture, the relationship between strategic alliance and ICT in Indonesia may be different from other countries; therefore, further investigation into whether the engagement in SA in Indonesia also leads to the use of communication technology, such as the use of the intranet and Internet, is warranted. Following this discussion, we posit that:

H1: A positive relationship exists between a firm's engagement in strategic alliance and its managerial use of ICT.

\section{Managerial Use of ICT and CRP}

Due to competition, manufacturers need to have updated and instant information to meet customers' demands and preferences. Customised products and services have become essential for meeting customers' expectations. Customers also 
demand an integrated service and quick responses. Therefore, a company ${ }^{1}$ now has to focus on its customer-related performance; otherwise, competitors will take over its market opportunities (Andel, 2002). CRP in this study incorporates attributes such as the on-time delivery of orders, the number of customer complaints received, market share, the time between receiving an order to delivery, and customer response time. The extant literature suggests that the use of ICT is positively associated with a firm's performance. Andersen (2001) reported that ICT, by facilitating the rapid sharing of accurate information at little cost, allows organisations to have the instant online information needed for prompt decision-making. For example, in a highly competitive market, customers' needs and tastes and competitors' products change rapidly and unexpectedly. With the intranet aspect of ICT, marketing departments are able to inform their production departments of the demand trend for product(s) in a timely manner, enabling the production department to effectively adjust production processes to meet customers' changed tastes and needs. Supporting this study, Choe (2008) found that information sharing throughout a company's value chain improves organisational performance, whereas Quader and Quader (2008) reported that UK supermarkets - through engagement in strategic alliances with Internet-based companies - can take customers' orders online and deliver the orders quickly, thereby raising their customer-related performance (see also Lee \& Ding, 2010). Similarly, Vanpoucke et al. (2009) supported previous studies and reported that communication among alliance members, such as suppliers, enhances a company's customer-related performance. Furthermore, Ramanathan (2013) suggested that the use of ICT in hospitals facilitates service to patients as the use of ICT in the hospital increases service speed, including responsiveness to patients, by linking not only communication among all the departments within the hospital but also with its suppliers and patients.

The discussion this far leads us to posit that a firm's managerial use of ICT is positively related to its customer-related performance. This argument is formalised in our second hypothesis.

$\mathrm{H}_{2}$ : A positive relationship exists between managerial use of ICT and customer-related performance.

\section{Engagement in SA and Customer-Related Performance}

The relevant literature indicates that SA facilitates alliance member firms' access to broader markets with lower investment, assists them in facing environmental uncertainty, and improves their brand name, thereby enabling the firms to gain a

\footnotetext{
${ }^{1}$ The terms organisation, company' and firm are used as synonyms in this paper.
} 
competitive advantage (Shrader, 2001; Steensma \& Corley, 2000). According to Tehrani (2003), a manufacturing firm's engagement in a SA has a positive impact on the firm's product quality because an alliance with suppliers, for instance, helps the firm obtain quality materials and spare parts; this also may result in increased productivity. Furthermore, the alliance supplier(s) helps member firms respond faster to customer demand as well as maintain and improve customer services. Jiang and Li (2009), for instance, reported that engagement in SA significantly contributes to partner firms' performance. In other studies, researchers have suggested that engagement in SA improves the availability of quality service as well as brand image, which ultimately improves market share. For example, the brand image combination of IBM and Intel or Bacardi Rum and Coca Cola has improved the products' quality image and increased their market share (Akshay, Rueket, \& Robert, 1994). Similarly, the alliance between Rover and Honda has improved the brand image of the products. Alvarez and Gonzales (1999) reported that Honda's design of a Rover model increased the alliance partners' product image and reputation in terms of reliability and quality. Similarly, through Arnotts' (a biscuit maker in Australia) alliance with other local biscuit manufacturers, Arnotts has been able to beat the competitors in gaining additional shares in the local market. By forming an alliance with America's Campbell Soup, Arnotts also entered the American market; by making and selling American Campbell cookies, it increased its Australian market share to 75\% (Dettre, 1986).

The relevant literature also indicates that a strategic alliance assists member firms in managing their inter-organisational dependency, improving brand name, and maintaining control over markets by gaining competitive advantages (Shrader, 2001; Steensma \& Corley, 2000). For example, Wang and Horsburg (2007) reported that a network of interlinked services with alliance member firms improves the service consistency of airlines, which ultimately improves their customer satisfaction.

Following this discussion, it is argued that engaging in a SA improves member firms' customer-related performance. Hypothesis three formally presents this argument.

H3: A positive relationship exists between a firm's engagement in a strategic alliance and its customer-related performance.

However, the positive benefits of a strategic alliance discussed thus far are not universal, as some studies have reported that a strategic alliance has a negative direct relationship with a firm's performance. Ritala, Hallikas, and Sissonen (2008) and Walter, Lechner, and Kellermanns (2008) explained that, due to a lack of coordination between alliance firms, engagement in strategic alliance(s) indeed harms individual 
member firms' performance (see also Rajasekar \& Fouts, 2009). We contend that one reason for such an undesirable effect on performance is the lack of trust and cooperation among alliance member firms. The relevant literature suggests that effective communication builds trust among alliance member firms, thereby fostering close cooperation among the firms (Abodor, 2002; Collinson, 2000). We posit that the managerial use of ICT plays a mediating role in the relationship of a firm's engagement in SA and its performance because ICT facilitates close communication among member firms of a SA in a timely manner, thereby acting as a proxy for (or a driver of) trust, commitment, and collaboration among the alliance member firms while assisting in improving the firms' performance. In other words, we predict that ICT mediates the relationship between a firm's engagement in SA and its CRP. If the relationship between a firm's engagement in a SA and ICT $\left(\mathrm{H}_{1}\right)$ and the relationship between ICT and CRP $\left(\mathrm{H}_{2}\right)$ are positive and significant, the results then would indicate that the relationship between a firm's engagement in a SA and its CRP $\left(\mathrm{H}_{3}\right)$ exists, at least partly, via ICT. More specifically, in such a case, ICT would appear to play a mediating role in the relationship. A logical interpretation of such positive results would lead to the conclusion that the adequate managerial use of ICT assists an organisation's SA to be effective in improving the organisation's CRP.

\section{An Industry Comparison}

The sample of this study comprises firms from four different industries: electronics, food processing, furniture, and fabricated metal products. We contend that the mediating role of ICT in the firms from the electronics industry will be more pronounced than in the firms from the other three industries. Our argument is based on the theory of product life cycle (PLC) that prevails in these industries. The PLC theory describes the evolution of a product as measured by its sales over its lifetime (Cox, 1967; Kotler, 2003). Throughout its life, a product passes sequentially through the stages of introduction, growth, maturity, and decline (Grantham, 1997). A product with short PLC passes through the different stages of its life relatively quickly. Consider, for example, the case of a plasma TV. Within a few years of the introduction of plasma televisions in the market, LCD televisions also appeared. As a result, the popularity of plasma TVs declined rather sharply and may disappear from the market within a relatively short period. In other words, the plasma TV represents a product with a short PLC. On the other hand, products such as canned tuna or steel rods or rolling chairs have been on the market for decades; these products are still available and, therefore, have a long life cycle (see also Bangchokdee, 2008). 
Given that, in today's market, electronic products (e.g., TV, laptop computer, mobile phone) generally have a short PLC, we contend that the electronics industry is characterised by a shorter PLC than that in the food processing, metal products, or furniture industry. The extant literature indicates that the electronics industry has been affected by rapid technological changes, unstable demands, volatile competition, and market growth (Geletkanycz \& Hambrick, 1997; Henderson, Miller, \& Hambrick, 2006). The literature contains evidence suggesting that the electronics industry specifically is characterised by rapid changes in product technology (Mendelson \& Pillai, 1999; Nadkarni \& Narayanan, 2007). For instance, Mendelson and Pillai (1999) reported that the capacity of microprocessors has doubled every two years, from 64 $\mathrm{Kb}$ to $256 \mathrm{~Kb}, 512 \mathrm{~Kb}$, and $1 \mathrm{Mb}$.

In contrast, industries with a relatively long PLC (e.g., the food processing industry) are characterised by relatively slow changes in technology, consistent market growth, and stable demand (Geletkanycz \& Hambrick, 1997; Henderson et al., 2006). Following the literature, we conclude that the electronics industry is characterised by a relatively short PLC while the food processing, furniture, and fabricated metal products (hereafter, other) industries are characterised by a relatively long PLC. Consequently, the level of uncertainty in the operating environment faced by these other industries is likely to be lower than the level of uncertainty faced by the electronics industry. For instance, Anderson (2004) reported that, compared to the food processing industry, the electronics industry faces a significantly high level of uncertainty.

We argue that industry-level uncertainty influences managerial use of ICT for decision-making. Managers in an industry facing a high level of uncertainty may make greater use of ICT to gather more information than those in an industry facing a relatively low level of uncertainty. In an industry facing a high level of uncertainty, managers require accurate and current information and data to gain a better understanding of the dynamics of the situation (Gordon \& Narayanan, 1984) and mount an appropriate response (Gul \& Chia, 1994; Mia, 1993) which, in turn, may enhance organisational performance (Chong \& Chong, 1997). On the other hand, in an industry facing a relatively low level of uncertainty, managers face a more stable business environment; therefore, they are able to cope with these situations as they can make decisions based on their past experiences (Gul \& Chia, 1994). Gul and Chia (1994) argued that, in a stable environment, managers may suffer from information overload if they access more information than needed, resulting in suboptimal decision-making, which may in turn lead to poor performance (Chong \& Chong, 1997). 
Although previous studies have examined the effect of uncertainty on the usefulness/use of accounting information (Chenhall \& Morris, 1986; Chong \& Chong, 1997; Gul \& Chia, 1994), these studies focused on the uncertainty at the organisation or individual level, not at the industry level. For example, the early study by Gordon and Narayanan (1984) examined the relationship between managers' perceived environmental uncertainty (PEU) and the perceived usefulness of accounting information. Chong and Chong's (1997) study examining the effect of managers' PEU on the use of accounting information also used Gordon and Narayanan's (1984) instruments. Chenhall and Morris (1986) investigated the relationship between managers' PEU and their perceived use of accounting information, which is again at the individual level. Their measurement instrument attempts to capture managers' perceptions of environmental uncertainty relating to the managers' operating environment at work. Unlike the previous studies, the current study focuses on uncertainty at the industry level.

The extant literature suggests that managers' use of ICT (i) increases volume, speed, and capacity of their data handling and (ii) improves information exchange and communication across functions, parties, geographical locations, and time zones (Badir, Büchel, \& Tucci, 2009; Andersen, 2001; Forouzan, 2001). Previous studies have reported that the extent of managers' information use is positively associated with their ICT use, as ICT helps them effectively use the information (see Brynjolfsson \& Hitt, 1996). Recently, Mia and Winata (2008) reported that managers' information use and their ICT use are positively related. The effective use of information is particularly relevant for the electronics industry given its high level of uncertainty. As an integrated computer network and data interface, ICT also provides managers with the capacity to instantaneously share real-time information that enables faster and better decision-making (Andersen, 2001). In light of this discussion, we posit that managers' use of ICT plays a more important role in the relationship between a firm's engagement in SA and its CRP in the electronics industry than in the other industries. Hypothesis four summarises this discussion.

$\mathrm{H}_{4}$ : The mediating role of ICT in the relationship between a firm's engagement in strategic alliance and its CRP is more pronounced in the electronics industry than in the other industries. Specifically, strategic alliance not coupled with the use of ICT will be less effective in the electronics industry than in the other industries. 


\section{RESEARCH METHOD}

\section{Sample}

Data were collected from 78 large (annual sales revenues from 50 to 150 billion rupiah; 1US $\$=11000$ rupiah) Indonesian manufacturing firms using a mailed questionnaire survey. Initially, a list of 600 large private manufacturing companies operating in Java Island in Indonesia was obtained from the Online Data Centre of Industry and Trading Department of the Indonesian government. From among these 600 large companies, 250 companies were selected at random. Only large manufacturing companies were selected because such companies are more likely to engage in SA and have more resources to afford the investment in state-of-the-art information facilities comprising modern information and communication technology. The sample distribution was classified into the four industries as follows: 36 in electronics (47.5\%), 13 in food processing (15.38\%), 14 in furniture (17.95\%), and 15 in fabricated and metal products $(19.23 \%)$.

\section{Participants}

Initially, a personal letter was written to the managing director (MD) or an equivalent senior executive at each of the selected 250 companies. The letter explained the purpose of the study, requested the MD to nominate one general manager in charge of a business unit (henceforth, BU manager) within the company to take part in the study, and solicited the executive's permission to contact the nominated BU managers. For the purposes of the study, a business unit was defined as a profit centre which carried out the usual business activities, including manufacturing and selling products (Mia, 2000). A sample of the survey questions used for the data collection was attached to the letter addressed to each MD. Within four weeks of posting the letter, we contacted the MDs by telephone, asking if they had received the letter and if they would nominate their BU manager to participate. If the letter had not been received, we sent the letter again, asking the MDs to nominate a BU general manager.

In total, $160 \mathrm{BU}$ managers were nominated by $160 \mathrm{MDs}$, who supplied the BU managers' names and addresses. Each of the nominated BU managers was subsequently sent a package that contained (i) a personal letter addressed to each BU manager explaining the purpose of the study, the potential benefit of the study, and an assurance of confidentiality of the responses; (ii) a copy of the survey questionnaire; and (iii) a self-addressed postage-paid envelope for returning the completed questionnaire directly to the researcher. The letter to each BU manager also explained that the questionnaire would not ask for any sensitive information and the information 
collected would be treated as strictly confidential. Moreover, the letter indicated that a copy of the summary results would be made available to the managers, subject to their completion of the request form for results included in the package.

In total, $78 \mathrm{BU}$ managers fully completed and returned the questionnaire. Thus, the final sample used for data analysis was 78, yielding a response rate of $31.20 \%$. Although the response rate was relatively low, the sample size was acceptable. Page and Meyer (2000) explained that the rule of thumb is at least four sample elements for every variable included in the study. The model of the current study included three variables: (i) engagement in a strategic alliance, (ii) managerial use of information and communication technology, and (iii) firm performance.

To test for non-response-bias, we split the sample into three groups based on the dates of the questionnaire's return. Statistical comparisons using the KruskalWallis Test did not indicate any significant difference between the groups ( $p>.10)$. Hence, non-response-bias was not a critical issue in the sample.

\section{Measurement of The Variables}

\section{- Firm performance}

Following the balanced scorecard approach (Kaplan \& Norton, 1996) and given the importance of CRP discussed earlier in Section 2, we used CRP as the firm performance. This variable was defined in terms of on-time delivery, the number of customer complaints received, market share, and customer response time (Hoque \& James, 2000). The BU managers were asked to indicate, on a 5-point Likert scale, their business unit's CRP relative to the average of the industry. On the scale, 1 represented well below average and 5 represented well above the industry average performance. Table 1 presents the mean and standard deviation for the variable.

Table 1 Descriptive Statistics (total sample: $\mathrm{n}=78$ )

\begin{tabular}{llllll}
\hline Variables & Mean & Median & Std. dev. & Skeweness & Kurtosis \\
\hline Strategic alliance & 2.49 & 2.50 & 1.08 & 0.19 & 0.48 \\
\hline Info and Comm tech. & 2.85 & 3.07 & 1.14 & -0.03 & -1.26 \\
\hline Customer-related perf. & 3.42 & 3.50 & 0.60 & -0.59 & 0.47 \\
\hline
\end{tabular}

\section{- Information and Communication Technology}

This study focused on the managerial use of ICT comprising the Internet, intranet, and visual communication, including videoconferencing and net-meetings (Forouzan, 2001). The measurement of this variable involved assessing the extent of managerial use of the Internet and intranet (Andersen, 2001; Byrd et al., 2000). The 
extent of managers' use of ICT was assessed on a 5-point Likert scale ranging from 1 (almost never) to 5 (almost always). The instrument was adapted from Andersen (2001). The participants were asked to respond to each of the 5 items indicating the extent of ICT use within their business units. Table 1 presents the mean and standard deviation for the variable.

\section{- Engagement in strategic alliance}

For the purposes of this study, SA was defined as a cooperative mutual agreement between autonomous organisations with a view to improving the competitive advantage and long-term profitable value for all cooperating parties. The agreement may or may not involve cross-partner equity investments (Miles \& Snow, 1992). The extent of a firm's engagement in a SA was measured on a 5-point Likert scale, ranging from strongly disagree (low alliance) to strongly agree (high alliance). The instrument consisted of 4 items referring to the extent of agreement between the respondent BU manager's firm and its alliance member companies in developing, producing, and marketing products. The BU managers (respondents) were asked to respond to each of the four items (questions), indicating the extent of their company's mutual agreement or business network with their company's alliance partners. The instrument was adapted from Li and Atuahene (2001). Table 1 presents the mean and standard deviation for the variable.

\section{DATA ANALYSIS}

To test the hypotheses we conducted a partial least squares (PLS) analysis. PLS is a variance-based structural equation modelling approach that has been developed to avoid some of the limitations of the well-known covariance-based techniques like LISREL. Structural equation models in general allow the researcher to represent, estimate, and test complex relationships between theoretical constructs (latent variables) - namely, variables that are not directly observable and can be measured only imperfectly through manifest indicators. Although covariance-based techniques like LISREL require a certain sample size and distribution assumptions, PLS is able to handle a small sample size and non-normal distributions (Chin, 1998). PLS has recently been used in a number of empirical studies in accounting research (Anderson et al., 2002; Chenhall, 2004; 2005).

A structural equation model using PLS consists of a measurement model and a structural model. The measurement model depicts the relationship (loadings) between manifest indicators and the corresponding latent variable. The structural model involves the relationships between latent constructs themselves, thereby representing 
the theoretical model of a study (Hair et al., 2006; Chin, 1998). The estimation of structural equation models with the PLS procedure comprises two central steps. The first step is concerned with the iterative estimation of the constructs composed of their manifest indicators. After a solution converges on a set of indicator weights used for estimating the construct scores, the second step involves the non-interactive estimation of the structural model (Seltin \& Keeves, 1994).

To assess the reliability and validity of a measurement model, we look at the individual-item reliability, the internal consistency, and the convergent and discriminant validity (Barclay, Higgins, \& Thompson, 1995; Fornell \& Larcker, 1981; Hulland, 1999). The rule of thumb is that loadings should exceed .7. To assess internal consistency, the composite reliability for each construct is calculated; composite reliability looks at all the loadings of the manifest indicators composing a latent variable and is similar to Cronbach's alpha (Chin, 1998; Fornell \& Larcker, 1981). Values of .7 or above are recognised as good for the composite reliability measure. Convergent validity is assessed by calculating the average variance extracted (AVE) which represents the average variance shared between a construct and its indicators. Usually, it is recommended that the AVE should exceed .5, indicting that $50 \%$ or more variance of the indicators are accounted for by the construct (Barclay et al., 1995; Chin, 1998; Hulland, 1999; Fornell \& Larcker, 1981). To test for discriminant validity, demonstrating that a given construct is different from other constructs, the AVE of each construct must be greater than the squared correlation between the constructs and all other constructs (Barclay et al., 1995; Chin, 1998; Fornell \& Larcker, 1981).

After assessing the reliability and validity of the measurement models, the standardised path coefficients derived from PLS estimation are used to measure the relationships among the constructs and, hence, the hypothesised theoretical relationships. To assess the statistical significance of the path coefficients, the nonparametric bootstrapping procedure is used (Chin, 1998). In the present study, 500 bootstrapping samples were used to estimate standard errors. In addition to the statistical significance of the path coefficients, the predictive power of a model is examined using the squared multiple correlation coefficient (i.e., $\mathrm{R}^{2}$ value) for the endogenous (predicted, dependent) constructs. Corresponding values are interpreted in an identical manner as traditional regression (Barclay et al., 1995; Chin, 1998; Hulland, 1999).

Consistent with our discussion leading to hypothesis $\mathrm{H}_{4}$, the total sample was divided into two subsamples: one comprising the electronics firms, called the electronics industry, and the other comprising firms in the food processing, furniture, 
and fabricated metal products, called the other industries. Subsample one includes 36 firms and subsample two includes 42 firms. The analysis of data for each subsample is carried out separately using the same procedure followed for the total sample.

\section{RESULTS}

Table 2, presenting the bivariate correlation among variables for the total sample, reveals no multicollinearity issue. Validation results of measurements of the three variables in the study are shown in Table 4 and indicate acceptable results for the three constructs: CRP, use of ICT, and engagement in SA. The corresponding items of each construct show loadings above 0.7 , indicating acceptable individualitem reliabilities. The composite reliabilities of the three constructs were 0.892 for CRP, 0.965 for ICT, and 0.888 for SA. Thus, all constructs reached satisfactory levels of internal consistency. The AVEs of the constructs in the study display values that exceed the recommended 0.5 , revealing that the shared variance between the constructs and its items exceeds 50\%. In addition, Table 3 reports the Cronbach (1951) alphas which reach satisfactory levels at $0.834,0.954$, and 0.835 , respectively.

Regarding the discriminant validity, Table 4 presents the squared intercorrelations between the constructs for the total sample. The AVE of each construct is shown on the diagonal of the matrix. The results show that the AVE of each construct is greater than the squared correlations with other constructs, indicating that all constructs denote discriminant validity in this study. In summary, all the tests for reliability and discriminant validity show acceptable measurement properties for the three constructs.

After assessing the reliability and validity of the measurement models, the hypothesised relationships among the constructs were evaluated. The strength of the path relationships (path coefficients) and the variance explained are presented in Table 5. The squared multiple correlation coefficient for the estimated structural equation model amounted to $15.5 \%$ for ICT and $11.3 \%$ for CRP, indicating that SA as well as SA together with ICT explains a moderate portion of the variance of ICT and CRP, respectively.

Tables 2 The bi-variate correlation between the variables (total sample: $n=78$ )

\begin{tabular}{llll}
\hline Variables & 1 & 2 & 3 \\
\hline 1. Strat alliance (SA) & 1.00 & & \\
\hline 2. Info and com tech (ICT) & 0.33 & 1.00 & \\
\hline 3. Customer related perf (CRP) & 0.05 & 0.39 & 1.00 \\
\hline
\end{tabular}


Table 3 Measurement Statistics for Validity and Reliability of Measurement Models

\begin{tabular}{|c|c|c|c|c|c|c|}
\hline Indicators & $\begin{array}{l}\text { Cronbach } \\
\text { alpha }\end{array}$ & $\begin{array}{l}\text { Standardized } \\
\text { Loadings }\end{array}$ & $\begin{array}{l}\text { Composite } \\
\text { Reliability }\end{array}$ & AVE & Mean & Std. Dev. \\
\hline $\begin{array}{l}\text { Critical } \\
\text { Values } \\
\end{array}$ & $>.7$ & $>.7$ & $>.7$ & $>.5$ & & \\
\hline SA1 & \multirow{4}{*}{.835} & .82 & \multirow{4}{*}{.888} & \multirow{4}{*}{.665} & 2.27 & 1.31 \\
\hline SA2 & & .79 & & & 2.76 & 1.40 \\
\hline SA3 & & .86 & & & 2.23 & 1.28 \\
\hline SA4 & & .80 & & & 2.51 & 1.39 \\
\hline ICT1 & \multirow{5}{*}{.954} & .88 & \multirow{5}{*}{.965} & \multirow{5}{*}{.845} & 2.77 & 1.30 \\
\hline ICT2 & & .92 & & & 3.09 & 1.32 \\
\hline ICT3 & & .94 & & & 2.78 & 1.39 \\
\hline ICT4 & & .93 & & & 2.88 & 1.34 \\
\hline ICT5 & & .92 & & & 2.72 & 1.28 \\
\hline CRP1 & \multirow{4}{*}{.834} & .86 & \multirow{4}{*}{.892} & \multirow{4}{*}{.673} & 3.81 & .81 \\
\hline CRP2 & & .78 & & & 3.46 & .96 \\
\hline CRP3 & & .84 & & & 3.50 & .83 \\
\hline CRP4 & & .81 & & & 3.69 & .92 \\
\hline
\end{tabular}

Table 4 Squared Correlations between Constructs (total sample: $\mathrm{n}=78$ ) (diagonal elements represent AVE)

\begin{tabular}{llll}
\hline Variable & 1 & 2 & 3 \\
\hline 1. SA & $\mathbf{0 . 6 6 5}^{\mathbf{a}}$ & & \\
\hline 2. ICT & 0.154 & $\mathbf{0 . 8 5 4}$ & $\mathbf{0 . 6 7 3}$ \\
\hline 3. Perf. & 0.003 & 0.106 & .
\end{tabular}

a. Bold-faced elements on the diagonal represent AVE. For discriminant validity, the AVE in each row and column must be greater than the displayed squared correlations in that row or column. 
Table 5 Results from PLS Analysis with path coefficients (standardized) (total sample: $\mathrm{n}=78$ )

\begin{tabular}{lll}
\hline Relationship & ICT & CRP \\
\hline H1: Strategic alliance (SA) to ICT & $.39^{*}$ & \\
\hline H2: ICT to Customer Performance (CRP) & & $.36 \dagger$ \\
\hline H3: SA to ICT CRP???? & -.09 \\
\hline & $\mathrm{R}^{2}=.155$ & $\mathrm{R}^{2}=.113$ \\
\hline
\end{tabular}

$* \mathrm{p}<0.05, \dagger \mathrm{p}<0.025, \mathrm{p}<0.000$ (two-tailed)

Hypothesis $\mathrm{H}_{1}$ predicts a positive relationship between a manufacturing firm's engagement in a SA and its managers' use of ICT. The results presented in Table 5 show a significant path coefficient of $0.39(\mathrm{p}<.01)$, revealing that SA is positively associated with managers' use of ICT. Hence, the results support hypothesis one.

Hypothesis $\mathrm{H}_{2}$ predicts a positive relationship between managers' use of ICT and CRP. The corresponding path coefficient is statistically significant $(p<.01)$ and has a value of 0.36 , indicating that managerial use of ICT is positively associated with a company's CRP, thus supporting the hypothesis.

In Hypothesis $\mathrm{H}_{3}$, we predict a positive relationship between an organisation's SA and CRP. The insignificant path coefficient of -0.09 ( $p>.10)$ reveals that the SA is not associated with CRP. Therefore, hypothesis $\mathrm{H}_{3}$ is not supported. In other words, the results indicate that a SA is not directly associated with CRP.

In hypothesis $\mathrm{H}_{4}$, we predict that the role of ICT is more pronounced in the SACRP relationship in the electronics industry than in the other industries. More specifically, a SA not coupled with the use of ICT will be less effective in the electronics industry than in the other industries.

Similar to the total sample, Table 1 in the appendix, presenting the bivariate correlation between variables for each of the two subsamples, reveals no multicollinearity issue. As in the total sample, the validation of the three measurement models for each of the two subsamples (electronics and other industries) was assessed. The results presented in Table 3 reveal that the measurement models indicate acceptable results for the three constructs. The corresponding items in each construct show a satisfactory loading for both subsamples, indicating acceptable individual-item reliabilities. In addition, the composite reliabilities of the three constructs for both subsamples are satisfactory, thereby indicating a satisfactory level of internal consistency. The AVEs of the constructs for both of the subsamples display values 
that exceed the recommended 0.5 , revealing that the shared variance between the constructs and its items exceeds $50 \%$.

The satisfactory discriminant validity can be observed from Table 4, presenting the squared intercorrelations between the constructs for both subsamples. The AVE of each construct is shown on the diagonal of the matrix. The results show that the AVE of each construct for both subsamples is greater than the squared correlations with other constructs, indicating that all constructs denote discriminant validity in this study. In summary, all the tests for reliability and discriminant validity show acceptable measurement properties for the three constructs for both subsamples.

Having determined that the reliability and validity of the measurement models were satisfactory for both subsamples, hypothesis $\mathrm{H}_{\mathbf{4}}$ was tested. The level of significance (strength) of the relationships (path coefficients) and the variance explained are presented for both of the subsamples in Table 5. The percentage of variance $\left(\mathrm{R}^{2}\right)$ explained in ICT and CRP for each of the subsamples is also presented in the table. A striking difference in the results for the two subsamples is in the relationship between SA and CRP. Although the relationship between SA and CRP for other industries is not significant (the path coeff. $=0.08$ ), the same relationship for the electronics industry is highly significant and negative (the path coeff. $=-0.73$, $\mathrm{p}<0.000$ ). Table 6 summarises the differences in the results described herein.

Table 6 Results from PLS Analysis with path coefficients for the total and subsamples) ${ }^{\text {a }}$

\begin{tabular}{|c|c|c|c|c|c|c|}
\hline & \multicolumn{2}{|c|}{ Total sample, $\mathrm{n}=78$} & \multicolumn{4}{|c|}{ Other industries, $n=42$ Electronics, $n=36$} \\
\hline & ICT & CRP & ICT & CRP & ICT & CRP \\
\hline $\mathrm{SA} \rightarrow \mathrm{ICT}$ & .39 & & $.38 \dagger$ & & $.44 \dagger$ & \\
\hline $\mathrm{ICT} \rightarrow \mathrm{CRP}$ & & $.36 \dagger$ & & $.30 *$ & & $.63+\dagger$ \\
\hline $\mathrm{SA} \rightarrow \mathrm{CRP}$ & & -.09 & & .08 & & $-.73+\dagger$ \\
\hline & $\mathrm{R}^{2}=\mathbf{0 . 1 5 5}$ & $\mathrm{R}^{2}=0.113$ & $\mathrm{R}^{2}=0.15$ & $\mathrm{R}^{2}=0.11$ & $\mathrm{R}^{2}=0.20$ & $\mathrm{R}^{2}=\mathbf{0 . 5 3}$ \\
\hline
\end{tabular}

a. We used 500 bootstrapping samples to estimate standard errors

$* \mathrm{p}<0.05, \mathrm{p}<01, \uparrow \mathrm{p}<0.025, \uparrow \uparrow \mathrm{p}<0.000$ (two-tailed)

\section{DISCUSSION, LIMITATIONS, AND CONCLUSION}

We argued earlier in the paper that positive and significant relationships (hypotheses $\mathrm{H}_{1}$ and $\mathrm{H}_{2}$ ) would support the prediction that managerial use of ICT plays a mediating role in the relationship between a firm's engagement in a SA and its CRP. As the results reveal a significant and positive relationship between the SA and ICT 
$\left(\mathrm{H}_{1}\right)$ and between ICT and CRP $\left(\mathrm{H}_{2}\right)$, this prediction is supported. Indeed, the lack of support for the direct relationship between $\mathrm{SA}$ and CRP (i.e., $\mathrm{H}_{3}$ ) strengthens the argument for the mediating role played by ICT in the relationship between SA and CRP (Baron \& Kenny, 1986). Therefore, this study provides empirical evidence for the argument that a firm's engagement in a SA positively influences the firm's CRP via managerial use of ICT.

To provide an in-depth explanation of these results, we looked into the participant BU managers' responses to the individual items in the questionnaire for ICT. The responses revealed that, of the 78 BU managers, a very high percentage $(76 \%$ to $83 \%)$ of them indicated that managers in their organisations often to always use ICT to communicate with different people; collect information from different functions such as manufacturing, engineering, and other functional areas; and communicate with customers, suppliers, and alliance firms. We contend that such usage of ICT by managers from different functions in the alliance member firms promotes close cooperation through clear and effective communication among them, thereby facilitating firms' performance. Indeed, our in-depth analysis of the participant BU managers' responses to the items in the questionnaire on their firm's performance revealed that $86 \%$ to $94 \%$ of the BU managers indicated their firm's performance was from quite above average to well above average related to the performance of the competitor firms. This revelation leads us to view that improving a firm's performance by entering into SA(s) with other firms requires effective and clear communications among alliance member firms, and the managerial use of ICT, acting as a mediating factor, facilitates such communications.

We also argue in hypothesis $\mathrm{H}_{4}$ that the mediating role of ICT in the relationship between SA and CRP is more pronounced in the electronics industry than in the other industries. Analysing the data separately for the electronics industry and for the other industries reveals a striking difference in the results for the SA-CRP relationship for the two subsamples. These results support the prediction in $\mathrm{H}_{4}$ that ICT plays a relatively more important role in the electronics industry than in the other industries. Specifically, the negative and highly significant SA-CRP relationship for the electronics industry suggests that an electronics firm's engagement in SA without adequate managerial use of the ICT is detrimental to the firm's performance. In other words, ICT's mediating role in the SA-CRP relationship is more pronounced in the electronics industry than in the other industries. In addition, the differential strength in the mediating role of ICT in the SA-CRP relationship for the electronics industry and for other industries highlights that ICT's mediating role is contextual, rather than 
universal, and industry characteristics (e.g., extent of product life cycle) are important contingencies. We offer the following explanations for these results.

The relevant literature indicates that a strategic alliance enhances its member firms' access to new markets, increases resource availability, and helps the companies adapt to environmental uncertainty (Li \& Atuahene-Gima, 2001; Shrader, 2001; Steensma \& Corley, 2000). Adobor (2002) and Collinson (2000) suggested that cooperation among alliance members is critical for improving customer-related performance including market share, timely delivery of orders, after-sale services and speedy negotiations (see also Buckley \& Casson, 1988; Dwyer, Schurr, \& Oh, 1987). Managerial use of ICT facilitates close communication, thereby promoting performance (Andersen, 2001).

As the level of uncertainty in the electronics industry is relatively high due to short product life cycles, the use of ICT plays a more important role in facilitating managerial decision-making, maintaining close relationships with suppliers and customers, and fostering close cooperation and commitment among alliance members (Abodor, 2002; Collinson, 2000).

Our study extends the work of Shrader (2001), who reported no relationship between the firms' engagement in strategic alliance and their performance. Shrader (2001) argued that other factors influence the strategic alliance and performance relationship. Our study revealed that managerial use of ICT is one such other factor influencing the relationship. Our results also support the work of Andersen (2001) and Ramanathan (2013), who argued that managerial use of ICT enhances organisations' communication and positively influences performance.

Several limitations of the study merit additional discussion. First, although companies representing four different industries participated in the study, all were in manufacturing industries. Therefore, the results may be specific to the manufacturing industry, meaning caution is necessary in generalising the results to other industries. Testing the model in service organisations, such as the hospitality and banking and finance industries, would be beneficial. Second, this study does not consider the different types of strategic alliances in which a firm can engage. The extant literature suggests that a strategic alliance may be vertical or horizontal, internal or external (Li \& Atuahene-Gima, 2001; Harrigan, 1985; Anderson \& Weitz, 1992). Future research investigating the role of ICT use in the relationship between a manufacturing firm's performance and its engagement in different types of strategic alliances would be beneficial for understanding whether the role of ICT use differs in different types of strategic alliances (Lorange et al., 1992). 
Despite these limitations, the results have implications for both theory and practice. The findings of the study contribute towards a better understanding of the role of ICT in augmenting organisational efforts to improve customer-related performance by engaging in strategic alliance. The current study, by introducing ICT as a mediator of the relationship between strategic alliance and customer-related performance of organisations, has unlocked an opportunity for further understanding of ways to improve the relationship. Future research in the area will benefit from testing ICT's role in the relationship in different industrial, economic, and organisational contexts.

In terms of practice, we contend that the findings of the study can help managers realise that engagement in a strategic alliance alone may not be enough to improve their organisations' desired performance. For this purpose, the success of engagement in a strategic alliance requires the managerial use of ICT to facilitate communications among the alliance member firms. Given that the role of ICT is more pronounced in the electronics industry, BU managers in the electronics industry may encourage their subordinate managers to make greater use of ICT for communications. Based on the results, we posit that senior managers in industries facing a high level of uncertainty due to factors like short product life cycle may benefit their firms more by encouraging subordinate managers to use ICT for communication.

\section{REFERENCES}

Adobor, H. (2002). Competitive success in an age of alliance capitalism: how do firms-specific factors affect behavior in strategic alliances? Advances in Competitiveness Research, 10(1), 71-99.

Akshay, R., Rueket, R. and Robert, W (1994). Brand alliances as signal of product quality. Sloan Management Review, 36(1), 87-97.

Alvarez, M.J. and Gonzales, P. (1999). Strategic alliances, organisational learning and new product development: the cases of Rover and Seat. R\&D Management, 29(4), 391 - 402. http://dx.doi.org/10.1111/1467-9310.00149

Andel, Tom (2002). From common to custom : the case for make to order. Material Handling Management, 57(12), 24-31.

Andersen, T.J. (2001). Information technology, strategic decision making approaches and organisational performance in different industrial settings. Journal of Strategic Information Systems, 10(2), 101-119. http://dx.doi.org/10.1016/S09638687(01)00043-9 
Andersen, T.J. and Segars, A, H. (2001). The impact of IT on decision structure and firm performance: evidence from textile and apparel industry. Information \& Management, 39(2), 85-100. http://dx.doi.org/10.1016/S0378-7206(01)00081-7

Anderson, E. and Weitz, B.A. (1992). The use of pledges to build and sustain commitment and distribution channels. Journal of Marketing Research, 9(1), 1834. http://www.jstor.org/stable/3172490

Anderson, S.W., Hesford, J.W. and Young, S.M. (2002). Factors influencing the performance of activity-based costing teams: a field study of ABC model development time in the automobile industry. Accounting, Organizations and Society, 27(3), 195-211. http://dx.doi.org/10.1016/S0361-3682(01)00057-5

Anderson, T.J. (2004). Integrating decentralized strategy making and strategic planning process in dynamic environments. Journal of Management Studies, 41(8), 1271-1299. http://dx.doi.org/10.1111/j.1467-6486.2004.00475.x

Badir, Y., Büchel, B., \& Tucci, C.. (2009). The performance impact of intra-firm organizational design on an alliance's NPD projects. Research Policy, 38(8), 1350-1364. http://dx.doi.org/10.1016/j.respol.2009.06.010

Bangchokdee, S. (2008). Linking competitive strategy, product life-cycle, the use of broad scope MAS information, and organisational performance: A comparative study of food processing electronic industries in Thailand. An unpublished $\mathrm{PhD}$ thesis, Griffith University.

Barclay, D., Higgins, C. and Thompson, R. (1995). The partial least squares (PLS) approach to causal modeling: Personal computer adoption and use as an illustration. Technology Studies, 2, 285-309.

Baron, R.M and Kenny, D.A. (1986). The Moderator-Mediator Variable Distinction in Social Psychological Research: Conceptual, Strategic, and Statistical Considerations. Journal of personality and social psychology, 51(6), 1173-1182. http://dx.doi.org/10.1037/0022-3514.51.6.1173

Brynjolfsson, E. and Hitt, M. (1996). Paradox lost? Firm-level evidence on the returns to information systems spending. Management Science, 42(4), 541-558. http://dx.doi.org/10.1287/mnsc.42.4.541

Buckley, P.J. and Casson, M. (1988). A theory of cooperation in international business. Management International Review, 1, 19-39.

Chen, C. C., Chen, X., \& Meindl, J. R. (1998). How can cooperation be fostered? the cultural effects of individualism-collectivism. The Academy of Management Review, 23(2), 285-304. http://dx.doi.org/10.5465/AMR.1998.533227 
Chenhall, R. H., \& Morris, D. (1986). The impact of structure, environment, and interdependence on the perceived usefulness of management accounting systems. The Accounting Review, 61(1), 16-35. http://www.jstor.org/stable/247520

Chenhall, R.H. (2004). The role of cognitive and affective conflict in early implementation of activity-based cost management. Behavioral Research in Accounting, 16(1), 19-44. http://dx.doi.org/10.2308/bria.2004.16.1.19

Chenhall, R.H. (2005). Integrative strategic performance measurement systems, strategic alignment of manufacturing, learning and strategic outcomes: an exploratory study. Accounting, Organizations and Society, 30(5), 395-422. http://dx.doi.org/10.1016/j.aos.2004.08.001

Chin, W.W. (1998). The partial least square approach to structural equation modeling. In: Modern Methods for Business Research, Marcoulides, G.A. (ed), Mahwah, pp. $295-336$.

Choe, J. (2008). Inter-organizational relationships and the flow of information through value chains. Information \& $\quad$ Management, 45(7), 444. http://dx.doi.org/10.1016/j.im.2008.06.006

Chong, V. K., \& Chong, K. M. (1997). Strategic choices, environmental uncertainty and SBU performance: a note on the intervening role of management accounting systems. Accounting and Business Research, 27(4), 268-276. http://dx.doi.org/10.1080/00014788.1997.9729553

Collinson, S. (2000). Learning from the best. Strategic Direction, 16(4), 24-26.

Connell, J., \& Voola, R. (2007). Strategic alliances and knowledge sharing: Synergies or silos? Journal of Knowledge Management, 11(3), 52-66. http://dx.doi.org/10.1108/13673270710752108

Cox, W. E. (1967). Product life cycles as marketing models. The Journal of Business, 40(4), 375-384. http://www.jstor.org/stable/2351620

Cronbach, L. J. (1951). Coefficient alpha and the internal structure of tests.psychometrika, 16(3), 297-334. http://dx.doi.org/10.1007/BF02310555

Dewett, T., \& Jones, G. (2001). The role of information technology in the organization: A review, model, and assessment. Journal of Management, 27(3), 313-346.

Fornell, C. and Larcker, D.F. (1981). Evaluating Structural Equation Models with Unobservable Variables and Measurement Error. Journal of Marketing Research, 18(1) 39-50. http://dx.doi.org/10.2307/3151312

Forouzan, B.A. (2001). Data Communication and Networking. 2nd edition, Boston, Mcgraw-Hill. 
Geletkanycz, M. A., \& Hambrick, D. C. (1997). The external ties of top executives: implications for strategic choice and performance. Administrative Science Quarterly, 42(4), 654-681. http://dx.doi.org/10.2307/2393653

Gordon, L. A., \& Narayanan, V. K. (1984). Management accounting systems, perceived environmental uncertainty and organization structure: an empirical investigation. Accounting, Organizations and Society, 9(1), 33-47. http://dx.doi.org/10.1016/0361-3682(84)90028-X

Grantham, L. (1997). The validity of the product life cycle in the high-tech industry. Marketing Intelligence \& Planning, 15(1), 4-10. http://dx.doi.org/10.1108/02634509710155606

Gul, F. A. and Chia, Y. M. (1994). The effects of management accounting systems, perceived environmental uncertainty and decentralization on managerial performance: A test of three-way interaction. Accounting Organizations and Society,19(5), 413 - 426. http://dx.doi.org/10.1016/0361-3682(94)90005-1

Gulati, R. (1998). Alliances and Networks. Strategic Management Journal, 19(4), pp. 293 - 317. http://www.jstor.org/stable/3094067

Hair, J.F., Black, B., Babin, B.J., Anderson, R.E. and Tatham, R.L. (2006). Multivariate Data Analysis, 6th Edition, Upper Saddle River.

Harrigan, K.R. (1985). Strategies for joint ventures. Lexington, Mass: Lexington Books.

Haywood, R. (1999). From paper to intranet, IIE Solutions, 31(2), 47-50.

Hill, W.C. (2010), International business: Competing in the global marketplace (8th ed.). New York, NY: McGraw-Hill

Hofstede, G.H. (1994). Cultures and organisations, London: Harper Collins Publishers. Hoque, Z. and James, W. (2000). Linking balanced scorecard measures to size and market factors: impact on organisational performance. Journal of Management Accounting Research, 12(1), 1-17. http://dx.doi.org/10.2308/jmar.2000.12.1.1

Hulland, J. (1999). Use of partial least squares (PLS) in strategic management research: a review of four recent studies. Strategic Management Journal, 20(2), 195-204. http://www.jstor.org/stable/3094025

Jiang, X., \& Li, Y. (2009). An empirical investigation of knowledge management and innovative performance: The case of alliances. Research Policy, 38(2), 358 http://dx.doi.org/10.1016/j.respol.2008.11.002

Kaplan, S.R. and Norton, D.P. (1996). Using the Balance Scorecard as a strategic management system. Harvard Business Review, 74(1), 75-86.

O'Connell, T. (2002). Growing internet market, competition demand web presence. SDM, 32(4), 11-11-12. 
Kotler, P. (2003). Marketing management (11th ed.). Upper Saddle River, N.J.: Prentice Hall.

Lee, H., \& Ding, J. (2010). The effects of e-business on the performance of strategic alliances. Total Quality Management \& Business Excellence, 21(7), 707-724.

Li, H. and Atuahene-Gima, K. (2001). Product innovation strategy and the performance of new technology ventures in China. Academy of Management Journal, 44(6), 1123-1134.

Lorange, P., Roos, J. and Bronn, P. (1992). Building successful strategic alliance. Long Range Planning, 25(6), 10-17. http://dx.doi.org/10.2307/3069392

Luo, Y. (2008). Structuring interorganizational cooperation: the role of economic integration in strategic alliances. Strategic Management Journal, 29(6), 617-637. http://dx.doi.org/10.1002/smj.677

Mendelson, H. and Pillai, R. R. (1999a). Industry clockspeed: measurement and operational implications. Manufacturing \& service operations management, 1(1), 1-20. http://dx.doi.org/10.1287/msom.1.1.1

Mia, L. (1993). The role of MAS information in organisations: an empirical study. British Accounting Review, 26(3), 269-285. http://dx.doi.org/10.1006/bare.1993.1026

Miles R. and Snow, C. (1992), Causes of failure in networked organisations. California Management Review, 34(4), 53-72.

Nadkarni, S. and Narayanan, V. K. (2007). Strategic schemas, strategic flexibility, and firm performance: the moderating role of industry clockspeed. Strategic Management Journal, 28(3), 243-270. http://dx.doi.org/10.1002/smj.576

Quader, S., \& Quader, R. (2008). The utilization of e-commerce by traditional supermarkets in the UK through strategic alliances with internet based companies. Journal of Services Research, 8(1), 177-211

Ranaweera, C., \& Prabhu, J. (2003). On the relative importance of customer satisfaction and trust as determinants of customer retention and positive word of mouth. Journal of Targeting, Measurement and Analysis for Marketing, 12(1), 82-82-90. http://dx.doi.org/10.1057/palgrave.jt.5740100

Ritala, P., Hallikas, J., \& Sissonen, H.. (2008). The effect of strategic alliances between key competitors on firm performance. Management Research, 6(3), 179187. http://dx.doi.org/10.2753/JMR1536-5433060302

Seltin, N. and Keeves, J.P. (1994). Path analysis with latent variables. In: Husten, T., Postlethwaite, T.N. (Eds.). International encyclopedia of education, 2nd Edition, London, pp. $4352-4359$. 
Shrader, R.C. (2001). Collaboration and performance in foreign markets: The case of young high-technology manufacturing firms. Academy of Management Journal, 44(1), 45-60. http://dx.doi.org/10.2307/3069336

Steensma, H.K. and Corley, K.G. (2000). On the performance of technology-sourcing partnerships: The interaction between partner interdependence and technology attributes. Academy of Management Journal, 43(6), 1045-1067. http://dx.doi.org/10.2307/1556334

Tehrani, M. 2003. Competitive Strategies, Strategic Alliances, and Performance in International High-tech Industries: A Cross-cultural Study. Journal of American Academy of Business, 2 (2), 610-617

Triandis, H. C. 1995. Individualism and collectivism. Boulder, CO: Westview.

Vanpoucke, E. , Boyer, K .,\& Vereecke,A. ,(2009). Supply chain information flow strategies: an empirical taxonomy. International Journal of Operations \& Production Management, 29(12), 1213-1241 http://dx.doi.org/10.1108/01443570911005974

Villas, M. V., \& Macedo-Soares, T. (2007). The influence of strategic alliance networks on information and communication technology : results of an exploratory empirical study. Journal of Global Business and Technology, 3(1), 116.

Walter, J., Lechner, C., \& Kellermanns, F.. (2008). Disentangling Alliance Management Processes: Decision Making, Politicality, and Alliance Performance. The Journal of Management Studies, 45(3), 530-560. http://dx.doi.org/10.1111/j.1467-6486.2007.00749.x

Wang, Z. H. and Horsburgh, S. (2007). Linking Network Coherence to Service Performance: Modelling Airline Strategic Alliances. Journal of Marketing Channels, 14(3), 51-81. http://dx.doi.org/10.1300/J049v14n03_04

Whipple, J.M. (2000). Strategic alliance success factors. The Journal of Supply Chain Management, 36(3), 21-28. http://dx.doi.org/10.1111/j.1745-493X.2000.tb00248.x 